\title{
Kant's View on Moral Education
}

\begin{abstract}
Ahmet YAYLA *
ABSTRACT. In this writing, how education is comprehended and especially what his opinions in relation to the education on ethics are evaluated through the eyes of a philosopher of ethics, that's Kant who possessed a specific place in ethics history and pioneered of an era by his thoughts in relation to ethics. Kant believed in the natural purity and goodness of man who can reach perfection only through education. He defined ideal education as a process of disciplining, socializing, civilizing and moralizing of man's nature. To him, the ideal education is to train man's will in accordance with the principles of reason, i.e., principles of ethics, not with those of natural and material desires. The purpose of this paper is to examine Kant's approach to education and moral education based on his philosophy of ethics. The main argument of this paper is based on the premises that Kant's view on education is actually a complementary part of his philosophy of ethics.
\end{abstract}

Key Words: Education, ethics, moral education, duty, discipline.

\section{SUMMARY}

The purpose of this paper is to examine Kant's approach to education and moral education based on his philosophy of ethics. The main argument of this paper is based on the premises that there are close affinity between Kant's view on education and his philosophy of ethics to the extent that one can safely suggest that Kant's view on education is actually a complementary part of his philosophy of ethics. A through examination of Kant's Works in logical order clearly reveals the fact that Kantian view of education is very complementary part of his philosophy of ethics. Under the influence of Rousseau at the beginning, Kant believed in the natural purity and goodness of man who can reach perfection only through education. He defined ideal

\footnotetext{
* Dr., Ankara University, Intitute of Social Sciences.
} 
education as a process of disciplining, socializing, civilizing and moralising of man's nature. To him, the ideal education is to train man's will in accordance with the principles of reason, i.e., principles of ethics, not with those of natural and material desires. Putting greater emphasis on discipline, Kant classified education into two categories as physical and ethical education.

According to Kant the main purpose of education is realizing a moralisation and humanisation based on the law of ethics. One should struggle with duty consciousness that is he/she should act in accordance with the law of ethics, dominate on nature and improve an autonomous individuality in terms of ethics. Thus Kant supports the necessity that beginning from the possible earliest ages the children should be familiarized to 'duty' and 'discipline'. He claims that education of ethics should not be based on discipline instead it should be based on particular rules and laws by dealing with the education of ethics in accordance with the philosophy of ethics. He asserts that one should act in conform to such a law that he/she can expect it to be a universal law. That's way he advises that in the education of ethics children should be taught to act within the scope of general rules. Child thus learns to conform to universal law the accuracy of which he/she personally comprehend and puts up.

At the same time, the education of ethics contributes to the formation of child character. To Kant, character is the habit of acting in accordance with the law of ethics and a child whose character has formed can realize ethical actions. Besides Kant supports that there should not be 'award' and 'punishment' in the education of ethics, because an action which, is done because of the fear of punishment or the desire of reward has no ethical value. An ethical action is ethical only when it is good and virtuous in its essence and realized in accordance with the law of ethics. He is not important and valuable so much if a child display some desired behaviours without understanding and comprehending the good. What is important is his/her doing good because it is good and avoiding evil because it is evil. To Kant, the education of ethics should not teach the rules which the child is supposed to obey with pressure and fear instead it should teach them on the basis of understanding explanation and adopting. Only if the child is provided with such on education of ethics can he/she display conscious and ethical actions and can he/she be admitted as educated.

NOTE: This is an extended summary of the following article originally written in Turkish. 


\title{
Kant'ın Ahlak Eğitimi Anlayışı
}

\begin{abstract}
Ahmet YAYLA*
ÖZ. Bu yazıda, etik tarihinde önemli bir yere sahip olan ve etiğe ilişkin görüşleriyle yeni bir dönemin başlatıcısı olan bir ahlak filozofunun, Kant'ın gözünden eğitimin nasıl anlaşıldığı ve özellikle ahlak eğitimine yönelik fikirlerinin neler olduğu değerlendirilmeye çalışılacaktır. İnsan doğasının saf, temiz ve iyi olduğunu, insana ancak eğitim yoluyla en mükemmel şeklin verilebileceğini savunan Kant, ideal bir eğitimi, insan doğasını disiplin altına alma, toplumsallaştırma, medenileştirme ve ahlakileştirme süreci olarak tanımlar. İdeal bir eğitimi iradenin, doğal eğilimlere ve maddi isteklere değil, aklın ilkelerine yani ahlak yasasına uygun bir tarzda yetiştirilmesinde görür. $\mathrm{Bu}$ makalede filozofun eğitim hakkındaki düşüncelerinin ahlak felsefesini tamamlayıcı nitelikte olduğu öne sürülerek, bu bağlamda eğitim ve ahlak eğitimi görüşleri ele alınmaya çalışılacaktır.
\end{abstract}

Anahtar Sözcükler: Eğitim, ahlak eğitimi, ödev, disiplin.

\section{GİRIŞ}

Kant'ın etiğe ilişkin ileri ileri sürdüğü fikirler etik tarihi açısından bir dönüm noktasıdır. Kant'a karşı olan pek çok düşünür de dâhil olmak üzere daha sonraki felsefe yazılarının büyük çoğunluğu için etik, bir konu olarak Kantçı terimlerle tanımlanır. Hatta felsefeyle yakından ilgilenmeyen sıradan bir insanın bile etik denildiğinde aklına ilk gelebilecek isim herhalde Kant olurdu (MacIntyre, 2001:217). Çünkü Kant, kendi dönemine kadar ulaşan ve o güne kadar etik tarihine egemen olan 'Mutlulukçu Etik' anlayışlarını tersine çevirerek etikte yeni bir dönemin başlatıcısı konumunda olan önemli bir filozoftur. Etik tarihi açısından bu kadar önemli olan bir düşünürün elbette ki eğitime özellikle de ahlak eğitimine yönelik ilginç ve parlak düşünceleri olacaktır. Ancak Kant'ın ahlak felsefesiyle çok yakından ilişkili olan eğitim görüşleri, onun etik görüşü içinde göz ardı edildiğinden şimdiye

* Dr., Ankara Üniversitesi, Sosyal Bilimler Enstitüsü 
kadar hep geri planda kalmıştır. Bazı eğitim filozofları dışında pek çok kişi, Kant'ın eğitime ilişkin fikirlerini ya bilmemekte ya da ahlak eğitiminin önemi hakkında söylediklerini dikkate almamaktadır. Oysa etik tarihine yön veren ve etikte yeni bir dönemin başlatıcısı olan filozofun eğitime özellikle de ahlak eğitimine yönelik düşüncelerinin oldukça önemli olacağ Gerçi yaşadığı dönemin önde gelen düşünürlerinden Rousseau ve Pestalozzi'nin ortaya koyduğu eğitim kuramları, Kant'ın eğitim hakkındaki fikirlerinin gölgede kalmasına zemin hazırlamış olsa da, ahlak eğitimi ile ilgilenenlerin, böylesi büyük ve önemli bir ahlak filozofunun eğitime yönelik düşüncelerine ilgisiz kalmaları düşünülemez. Zira onun ahlak felsefesi incelenirse, ahlak eğitimine yönelik bazı önemli tespit ve ipuçlarını bünyesinde taşıdığı görülecektir. Özellikle 'erdem' öğretiminin nasıl olması gerektiği üzerine incelemelerinde ileri sürdüğü fikirler, onun ahlak eğitimi ve ögretimine yönelik felsefi tespitleri olarak, ahlak eğitimi açısından oldukça önemlidir. Dolayısıyla Kant'ın eğitime dair düşünceleri ile ahlak felsefesi arasında yakın bir bağlantının olduğunu söyleyebiliriz. $\mathrm{Bu}$ makalede Kant'ın eğitim hakkındaki düşüncelerinin ahlak felsefesini tamamlayıcı nitelikte olduğu yönünde bir görüş ileri sürülecektir. Çünkü eserleri genel olarak mantık sırasına göre incelenirse, onun eğitime dair fikirlerinin ahlak felsefesine ilişkin düşüncelerini tamamlayıcı nitelikte olduğu görülebilir. Bu nedenle Kant'in eğitime ait bütün görüssleri üzerinde durmak gerektiği noktasından hareketle, onun ahlak eğitimine yönelik fikirlerine ahlak felsefesiyle de bağ kurularak dikkat çekilmesi, ahlak eğitimine yeni açılımlar getirmesi açısından oldukça önemlidir.

Kant'ın eğitim açısından önemi, yalnızca görev yaptı̆̆ üniversitede pedagoji üzerine vermiş olduğu derslerden değil, ortaya koyduğu görüşler ve felsefi kuramının, özellikle de etikle ilgili kuramının, diğer eğitim kuramları üzerinde derin bir etki yaratmış olmasından ileri gelmektedir (Aytaç, 1980:231). Kant doğrudan eğitim hakkında bir kitap yazmamıştır. Ancak bağli bulunduğu üniversitede mecburi olarak girdiği pedagoji derslerinde eğitime ilişkin düşüncelerini ortaya koyduğunu biliyoruz. Kant pedagoji derslerini verirken aynı zamanda çeşitli gözlemlerde bulunuyor, notlar alıyor ve yeni düşünceler üretiyordu. Kant'ın ders notları ölümünden bir yıl sonra (1803) 'Pedagoji Üzerine Notlar' ismiyle yayınlanacaktır. Söz konusu kitap düzenli olarak tertip ve tasnif edilmiş bir eğitim kitabı olmaktan çok birbirine bağlı birtakım gözlemleri içermektedir (Davids, 1992:VI-VII). Demek ki, Kant bu eserinde bir eğitim sistemi ortaya koymuyor, yalnızca eğitimle ilgili bazı düşüncelerini, gözlemlerini ve tecrübelerini dile getiriyor. Ancak kendisinin eğitime ilişkin düşünceleri hakkında düzenli bilgiye sadece bu kitaptan ulaşabilmekteyiz. Bu nedenle Kant'ın eğitim görüşlerini bu eserini temele alarak değerlendirmeye çalışacağız. 


\section{İnsan Doğası ve Eğitim}

Kant'ın eğitime ilişkin düşüncelerinde Rousseau'nun etkisinde kaldığ ve ona büyük bir hayranlık duyduğu açıkça görülmektedir. Özellikle 'insana saygı','insan doğası' gibi düşüncelerini 'Emil' romanından esinlenerek geliştirmiştir (Bowyer, 1970:2129). Ona göre Rousseau, birtakım geleneksel ve saçma alışkanlık ve adetlerin uygulanması sebebiyle çocukların bebeklikten itibaren zihinlerinin, duygularının, karakterlerinin bozulduğunu romanında çok güzel ve açık bir biçimde ortaya koymuştur (Bkz.Rousseau, 2000:18-24). Önceleri Rousseau'nun fikirlerinden büyük ölçüde etkilenen Kant, daha sonraları ahlaka ilişkin görüşleri kafasında netleştikçe onun fikirlerinden yavaş yavaş uzaklaştı. Eğitimin konusunun kişiyi şu veya bu topluma göre yetiştirmek olmadığını, aksine çocuğu insanlık gayesi doğrultusunda eğitmek olduğunu iddia eden Kant, insanın içgüdülerinin zayıf ve insanı ideal gayeye ulaştırmada yetersiz olduğunu savunur. Doğal eğilimlerine serbest bir yön vermekle çocuğun yetiştirilemeyeceğini, özellikle eğitimcinin her şeyden önce insanlığa layık bir ideale sahip olması ve çocuğu bu ideale göre eğitmeyi görev olarak benimsemesi gerektiğini söyler. $\mathrm{Bu}$ bağlamda Kant, bir ölçüde çocuğun kendi özgürlüğüyle, toplumun meşru gördüğü zorlama ve baskıları uzlaştırmayı eğitimcinin görevi olarak düşünür.

Kant, Rousseau'nun etkisi altındayken onun insan doğasının iyi olduğu yönündeki görüşünü benimser. Buna göre insan doğasında kötülük yoktur. İnsanda ancak iyiliğin tohumları vardır. İnsandaki iyiliği geliştirecek olan ise eğitimdir. Bu bağlamda insan doğasının iyi olduğu görüşü, başlangıçta, Kant'ın eğitim anlayışının çıkış noktasını oluşturur. "Dünyadaki bütün iyiliklerin kaynağı eğitimdir. İnsanda gizil olarak bulunan bütün yetenekler ve tohumlar daima daha iyi yönde geliştirilmelidir. İnsanın doğasında kötülük yoktur. Kötülüğün tek sebebi, doğayı iyi eğitim prensipleri doğrultusunda kontrol altında tutmamak ve ona yön vermemektir. İnsanda ancak iyinin tohumları vardır" (Kant, 1992:15). Önemli olan insanda potansiyel halde bulunan iyiliğin eğitim aracılığıyla giderek daha fazla geliştirilmesidir. Çünkü o insanın, doğuştan iyiliğe yatkın ve iyilik yapma potansiyeline sahip olduğuna, ama bu potansiyelin bize doğuştan hazır bir şekilde verilmediğine, aksine geliştirilmesi gereken bir kaynak, bir imkan olduğuna inanır. Ona göre kötülüğün sebebi, insan doğasında bulunan potansiyel iyilik yetilerinin kurallarla desteklenmeyip, başıboş bırakılmasından kaynaklanmaktadır. İnsan doğasını kuralsız bırakıp yabanileşmeye terk etmek, yani insanın doğal eğilimlerine göre eylemler gerçekleştirmesi kötülüğün başlıca sebebidir.

Kötülüğü doğuran yegane sebebin insan doğasını iyi eğitim esaslarına doğru yönlendirmemekten kaynaklandığını ve eğitim yoluyla insanın iyi yola sevk edilebileceği düşüncesinde olan Kant, bu nedenle, eğitime büyük 
önem verir. İnsanın yalnızca eğitim yoluyla insan olabileceğine; eğitim yoluyla kendisini, kendi doğasını mükemmelleştirebileceğine ve eğitim sayesinde insana en mükemmel bir şeklin verilebileceğine inanan Kant, "eğitimin, insan doğasının mükemmelleşmesinin en büyük sırrını içerdiğine" dikkat çekmektedir (Kant, 1992:7). Ona göre, ancak eğitim yoluyla, doğuştan getirilen hasletler geliștirilerek en üst düzeye çıkabilirler. Bu yüzden Kant, "insanın insan oluşu ancak eğitim sayesindedir; eğitim ne yapabildiyse insan işte ancak odur" der (Kant, 1992:6).

Kant, ahlak felsefesine ilişkin görüşleri netleştikçe, Rousseau'nun etkisinden uzaklaşır ve insan doğasının aslında ne iyi ne de kötü olduğu görüşüne ulaşır. "İnsan ahlakı, doğal olarak iyi midir, kötü müdür? İnsan doğal olarak ne iyidir, ne de kötüdür. İnsan sadece ahlak yasası ve ödev bilincini geliştirmiş bir akla sahip olduğu zaman ahlaki bir varlık olur" (Kant, 1992:108). Yani insan dünyaya geldiğinde ahlakı tamamen oluşmuş değildir. Aklını ahlak yasasına ve ödev bilincine göre kullandığı zaman ahlaki bir varlık olur. Bununla birlikte denilebilir ki, insanda, onu kötülüğe sevk edecek eğilimler mevcuttur. Çünkü insanın eğilimleri (arzu ve istekleri) ve içgüdüleri bir tarafa, aklı başka bir tarafa gider.

Ahlakla ilgili düşüncelerini geliştirdikçe, doğal eğilimlerle erdem arasında zitlı̆̆ daha belirgin bir şekilde ortaya koymaya başlayan Kant'a göre, doğal eğilimler insanı aklın, hür iradenin ortaya koyduğu yasaya aykırı yönde davranmaya yönlendirebilir. Söz konusu eğilimler aslında kötü olmasalar bile yine de, özgürlügümüze aykırı olarak eylemler gerçekleştirmemize yol açabilirler. Kant'a göre ahlaki açıdan iyi olmak ancak erdemle mümkündür. Erdem ise, mümkün olduğunca doğal eğilimlere teslim olmamak, yalnızca özgür olan ahlak yasasına itaat etmek üzere eylemde bulunmaya çalışmaktır. Kısacası Kant'a göre ahlaki açıdan olgunlaşmak, doğal eğilimlere göre değil, ahlak yasasına göre eylemde bulunmaya çalışmak demektir. Dolayısıyla ideal bir eğitim, iradenin doğal eğilimlere, maddi isteklere uymasına engel olan, bunun yerine iradenin aklın ilkelerine yani ahlak yasasına uygun tarzda yetiştirilmesine olanak tanıyan bir eğitimdir (Kant, 1992:108).

Öte yandan Kant'a göre "eğitime ihtiyaç duyan yegane varlık insandır. Eğitimle biz, kültürle birlikte yetiştirmeyi disiplini ve öğretimi anlamamız gerekir. Buna göre insan bebek, çocuk ve yetişkin süreçlerinden geçer" (Kant, 1992:1). Dolayısıyla varlıklar arasında aşama aşama gelişip mükemmelleşmesi için eğitime gereksinim duyan varlığın sadece insan olduğunu savunan Kant bu bağlamda, insanın çeşitli yönleri açısından diğer canlı ve cansız varlıklardan ayrıldığını söyler. Ona göre insanla hayvan arasında farklılıklar söz konusudur. Mesela hayvanlar düzenli bir plan doğrultusunda içgüdülerine bağlı olarak hareket ederler. Oysa insanların içgüdüleri yoktur, akıllarına göre hareket ederler. Zaten insanı diğer 
varlıklardan ayıran en temel özellik de onun akıllı bir varlık olması ve teknik bilgi üretebiliyor olmasıdır. İnsanla hayvan kıyaslandığında, hayvana göre insanın daha çok bakıma ve yardıma ihtiyacı olduğu ortadadır. Çünkü insan dünyaya geldiğinde hayvana göre daha aciz, yardım ve korunmaya muhtaç bir varlıktır. Adeta insan vahşi, ilkel bir varlık olarak dünyaya gelir. Hayatta kalabilmesi, hareketlerini yönlendirebilmesi için başkalarına ihtiyaç duyar. Oysa hayvanlar içgüdüsel olarak doğar doğmaz hayatla mücadelede başarılı olabilme potansiyeline sahiptirler. Hayvanların beslenmeye ihtiyaç duydukları doğrudur, ama onlar bakıma ihtiyaç duymazlar. İçü̈düsel hareket ederek yaşamlarını sürdürürler. Oysa insan akla muhtaçtır; hareketlerinin yönünü belirlemek durumundadır, geçeceği yolların haritasını önceden çizmek mecburiyetindedir ve kendi eylem planını yapmak zorundadır. Yine insan doğuştan getirdiği bir takım yeteneklerini mekaniksel olarak bir anda değil, aksine kendi çaba ve gayretleri sonucunda yavaş yavaş ve belli süreçlerden geçerek geliştirebiliyor (Kant, 1992:2).

Buna göre eğitimi, insan doğasını disiplin altına alma, toplumsallaştırma, medenileştirme ve ahlakileştirme süreci olarak tanımlayan Kant, bu konuda şunları yazar:

Eğitim insanlar1;

1-Disipline etmelidir. Bundan anlamamız gereken şudur: Disipline etmek, gerek bireysel, gerekse toplumsal yaşamda insandaki hayvani olan özelliklerin insani olan özelliklere üstün gelmesini engellemek demektir. Çünkü disiplin insanı kural tanımazlıktan (vahşilikten) sıyırıp çıkarır.

2-Eğitim insanı ayrıca kültürlendirmelidir. Bu kültürlenme bilgi ve öğretimi içerir, insanın yeteneğini ve gizil gücünü (potansiyelini) ortaya çıkarır. Yetenek değişik amaçlara ulaşmak için gerekli olan bilgi ve araçları üretme ve onları kullanabilme gücüdür. Yetenek kendi başına bir amaç değildir, ancak ehil kimse yeteneği doğrultusunda ve uygun şartlar çerçevesinde amacına ulaşabilir.

3-Eğitim kişiye şahsi karar verebilme yetisi sağlamalı, toplum içinde kendini sevdirerek yaşama yeteneği kazandırmalıdır. Kişiyi (adabı muaşeret) sahibi kılmalıdır.

4-Ahlak eğitimi, eğitimin bir parçası olmalıdır. İnsanın birçok amacının olması yeterli değildir. Kendisini bu amaçlara ulaştırabilecek ilkelerinin de olması gerekir. En iyi hedefler herkes tarafindan tasdik ve kabul edilirler; aynı zamanda her insanın amacı olabilirler [Öyle bir yasaya göre eylemde bulun ki bunun evrensel bir yasa olmasını arzu edebilesin (Kant, 1999:35)]. (Kant, 1992:18-19).

Kant'a göre, her nesil kendisinden sonra gelen neslin eğitim sorumluluğunu üstlenir ve böylece insanlık aşama aşama mükemmelleşir. Ayrıca Kant insanın doğal eğilimlerine uyarak kendi hedefinden, insanlığın 
gayesinden uzaklaşmaması için bir disipline, bir düzene gereksinim duyduğunu da ifade eder. Ona göre disiplin insan eğitiminin en önemli öğelerinden birisidir. "Disiplin insanı hayvani doğasından insani doğasına dönüştürür." Diğer bir ifadeyle "disiplin insanı, insani hasletlerden hayvani dürtüler yönüne dönüşen varlık olmaktan korur". Buna göre disiplin negatif bir eğitim tarzı olarak kabul edilebilir, çünkü disiplin insanın doğal eğilimlerine uymasını engeller ve başlangıçta doğasında var olan vahşiliği yok eder. Ayrıca eğitimin insanı insanlık idealine yaklaştıran olumlu bir yönü de vardır. Kant buna öğretim diyor. Vahşet, insanlığın yasalar karşısında kendisini tamamen bağımsız görmesidir. "Kurallara itaat etmeme yasadan bağımsız olmayı ifade eder". Yani vahşilik hiçbir kanunu tanımaz. Oysa Kant'a göre "disiplin, bireyi insanlık yasalarına itaat etmeye alıştırır ve yasaların gücünü ona hissettirir" (Kant, 1992:2-3). Dolayısıyla insanın yasalar karşısında kendisini başı boş hissetmesine engel olur.

Kant disiplinin çok erken yaşlardan itibaren oyun içinde çocuğa verilmesi gerektiğini savunur. Çünkü insanın doğal olarak özgürlüğe karş1 bir eğilimi söz konusudur. Uzun süre tekrar edilen davranışlar artık karakterimizin bir parçası olur ve alışkanlıklara dönüşür. Alışkanlık haline gelen davranışların daha sonra terk edilmesi oldukça zordur. Dolayısıyla zamanında eylemlerimiz bir disiplin ve düzen içerisinde alışkanlık haline dönüştürülmezse, sonra kazanacağımız kötü alışkanlıkların meydana getirdiği karakterimizi değiştirmemiz imkansız olur. Kant, insanın genç yaşlarda başı boş bırakılması ve hiçbir müdahalede bulunulmaması halinde yaşamının sonuna kadar vahşiliğe, ilkelliğe ait birtakım alışkanlıkları devam ettireceğine inanır. " $\mathrm{Bu}$ nedenle insan erken yaşlardan itibaren aklın düsturlarına riayet etmeyi alışkanlık haline getirmelidir. Eğer bir insanın gençlik dönemlerinde her istediğini yapmasına izin verilirse, onda yaşamı boyunca devam edecek kanun tanımazlık alışkanlığı kalır" (Kant, 1992:4). Demek ki Kant'a göre, insanları çocuk ve genç yaşlarda başı boş bırakır onlarla ilgilenmezsek hayatlarının sonlarına kadar terk edemeyecekleri birtakım kötü huylar edinmeleri kaçınılmaz olur. $\mathrm{Bu}$ nedenle Kantçı perspektiften çocuğun eğitiminde disiplinin zamanında verilmesi oldukça önemlidir. Disiplinin sağlanması bilgi verilmesinden daha önemlidir. Zira bilgi eksikliği hayatın herhangi bir döneminde telafi edilebilir, ancak disiplinsizlikten kaynaklanan ve karaktere dönüşen birtakım kötü alışkanlıklar düzeltilemez. Kısacası Kant'a göre bilgisiz insan sadece cahildir, oysa disipline tabi olmayan insan vahşidir (Kant, 1992:7).

Kant eğitimi, çocukluk ve gençlik olmak üzere iki döneme ayırır. Çocukluk döneminin yapısı ve özellikleri gençlik dönemine göre farklı olacağından onların eğitimi de farklı olacaktır. Çocuk küçük yaşlarında birçok şeyi doğal eğilimlerine göre yapar. Ancak çocuğa daha ilk yıllarından itibaren birtakım şeyleri ödev olduğu için yapma alışkanlığı kazandırılmaya çalışılmalıdır. Böyle bir alışkanlığın erken yaşlarda kazandırılması ileriki 
yaşlar için çok faydalı olur. Çünkü çocuk büyüyüp vatandaş olarak üstleneceği işlerde veya genel hizmetlerde hareketlerini doğal eğilimlerine göre değil de, ödev bilinciyle gerçekleştirecektir. Çocuğa aşama aşama isteklerine hakim olması, değişmez ilkelere itaat etme alışkanlığının kazandırılması yönünde ödev bilincinin yerleştirilmesine çalışılmalıdır. Ancak küçük çocuğa ödev fikrini anlatmak oldukça zordur. Çünkü itaat etmesi gereken kurallara neden itaat etmesi gerektiğini bilemez, sadece otoritenin emirlerine itaat eder. Oysa gençlik dönemlerinde durum değişir. Gençlik döneminde eğitimcinin çocuğa ödevin gerektirdiği kurallara neden itaat etmesi gerektiğine yönelik açıklamalar getirmesi gerekir. Çünkü çocuğun itaatiyle, olgunlaşan gencin itaati arasında fark vardır. Çocuk büyüdükçe körü körüne itaat, yerini ödev bilincine bırakır. İlk dönemlerde çocuk verilen emir ve tavsiyelere itaat etmesinden çok, bizzat emri veren otoriteye itaat eder. Oysa gençlik döneminde çocuk emir verenden çok, emrin bizzat kendisine itaat etmeye başlar. Yani bu ikinci dönemde çocuk emir veren otoriteye körü körüne itaatten çok, emirlerin ya da itaat etmesi gereken kuralların sebeplerine, gerekçelerine, kısacası akla itaat eder (Kant, 1992:85-86;Erişirgil, 1997:289-290).

Öte yandan Kant, "çocukları mevcut duruma göre değil, gelecekte insanın olası iyi bir haline yani insanlık idealine adapte olacak bir tarzda ve insanın bütün yazgısı (destiny) fikrine göre eğitmek gerek"tiğine inanır ve eğitimin bunun koşullarına uygun zemin hazırlaması gerektiğini söyler (Kant, 1992:14).

\section{Ahlak Eğitimi}

Kant eğitimi, fiziki eğitim ve ahlak (pratik) eğitimi olmak üzere ikiye ayırır. Kant'a göre "fiziki eğitim insanın hayvanlarla, sadece beslenme ve bakım yönünden ortak olan kısmıdır. Pratik (ruhi) veya ahlak eğitimi, bir insanın özgür bir varlık olarak nasıl yaşayacağını öğreten eğitimdir.” Kant pratik eğitimi de üç kısma ayırır: İlki çocuğun genel yeteneklerini geliştiren okul müfredatı; ikincisi yaşamın uygulamalı konularındaki öğretimi; üçüncüsü de ahlaki karakter eğitimi (Kant, 1992:30). Kant'ın bu tasnifini 'Kant on Education' kitabını tercüme eden Annett Churton şu şekilde açıklıyor: "1-Öğretim kişiyi kendisi için bir birey olarak değerli yapar. Öğretim aracılığıyla alınan bilgiler kişinin yeteneklerini geliştirmesine yardımcı olur. 2-Pratik eğitim kişiyi (devlet ve toplum için) bir vatandaş olarak değerli kılar -burada kişi medenileşme noktasında terbiye edilir. 3Ahlak eğitimi, kişiyi (insanlık için) bir insan varlığı olarak değerli yapar" (Churton, 1992:30). Görülüyor ki, Kantçı anlayışa göre insan kendi amaçlarına ulaşmak için birtakım bilgilere ihtiyaç duymaktadır. Dolayısıyla edineceği bilgiler kendisinin değerini de arttırmaktadır. Medeniyeti kazandıran eğitim, kişinin toplumsal değerini arttırarak onu yurttaş olmaya 
hazırlar. Kişi eğitim sayesinde topluma uyum sağlamayı ve ondan yararlanmayı öğrenir.

Kant'a göre, çocuk kendi bașına bırakılırsa büyüyemez dolayısıyla onun beden ve ruhunu oluşturmak ve idare etmek gerekir. Çocuklar tıpkı doğadaki eşyaya benzerler; nasıl ki maddi varlıklar doğa yasalarına göre idare ediliyorsa aynı şekilde çocukların davranışları da düzeltilmeli ve kontrol altında tutulmalıdır. Kant, çocuğun 'maddi varlık/şey' olmak açısından ihtiyaç duyduğu eğitime fiziki eğitim der. Kant çocuğun zihninin ilk yaşlarından itibaren birtakım alıştırmalara, usullere bağlı olarak geliştiğini ifade ederek zihinsel eğitimin de bir tür fiziki eğitim olduğunu kabul eder (Kant, 1992:66). İkinci olarak da pratik veya ahlak eğitiminden bahseder. Ona göre çocuk sadece bir 'şey' değil, aynı zamanda bir "şahsiyet" olma potansiyelidir. Çocuk ahlak eğitimiyle kendisinde var olan gizil gücün ortaya konulması ve geliştirilmesi sayesinde gelecekte kendi kendisini idare edecek, uygun gördüğü yasalara göre davranabilecektir. Kısacası doğal eğilimlere göre değil, kendisi tarafından kabul edilen veya ortaya konulan yasaya göre davranmayı öğrenerek mekaniksellikten özgürlüğe geçecektir (Kant, 1992:77).

Kant'a göre iyi bir şekilde eğitilen ve aydınlatılan insan, mantıklı olarak düşünebilme yetisi kazanır. Oysa hayvanlar sadece yetiştirilebilmektedir, onların düşünme yetilerini geliştirecek bir eğitim asla söz konusu olamaz. Kant, çocuğun sadece terbiye edilmesini yeterli görmüyor; onun için son derece önemli olan, çocuklara düşünmeyi öğretebilmektir. Kant’a göre düşünebilme yetisini geliştirebilen bir kimse ahlak yasasına göre eylemde bulunur. Öte yandan Kant, insan eyleminin tesadüfe bırakılamayacağına vurgu yaparak, eğitimin en önemli unsurlarından birinin ahlak eğitimi olduğunu savunur. Ancak filozof insan eğitimi için oldukça büyük öneme sahip olan ahlak eğitiminin ne yazık ki, ihmal edilmekte olduğunu öne sürer. Zira Kant'a göre "çocuklara gerekli olan bilgiler öğretiliyor da ahlak eğitimi ötekine berikine, tesadüfe, vaazlara, vaizlere (kiliseye) terk ediliyor". Halbuki Kant çocuklara, kötülükten nefret etmeyi ve kötülüğü Tanrının yasakladığı için değil, kötülüğü kötülük olduğu için yapmamayı ve ondan uzak durmayı öğretmenin çok daha önemli olduğunu dile getirir. Böylece erdemi erdem olduğu için benimsemeyi ve benimsetmeyi erdemlilik olarak kabul eder ve bu ilkeyi de ahlak eğitiminin temeline yerleştirir (Kant, 1992:20-21). Kant'a göre ahlaki bir eylem ne ceza korkusundan, ne de mükafat isteğinden dolayı yapılan bir eylemdir; aksine ahlaki bir eylem ahlak yasasına göre yapılan bir eylemdir. Ona göre ahlak eğitiminin temel hedefi, insanı ahlak yasasına uygun eylemler gerçekleştirebilecek, ödev bilincine ulaşmış özerk bireyler olarak yetiştirmektir.

Kant yaşadığı çağı disiplin, kültür ve medeniyet çağı olarak nitelemesine rağmen, ahlak eğitiminin yetersiz olduğunu düşünür. Kant 
çağının insan profilini analiz ederken insanlığın felakete, mutsuzluğa doğru sürüklendiğini, devletlerin geleceğinin tehlikede olduğunu ileri sürerek şu soruyu sorar: "İnsanlık şimdi bizim sahip olduğumuz ilimlerin bulunmadığ gayri medeni devirde acaba şimdikinden daha mutlu değil miydi?" (Kant, 1992:21). Kant, insanların ahlaklı ve erdemli olmadıç̧a mutluluğa ulaşamayacaklarını söyler. İnsanlar ahlaklı olmayınca kötülükten kendilerini alıkoyamazlar. İnsanların mutluluğa ulaşabilmelerinin ve devletlerin geleceklerine güvenle bakabilmelerinin yolu ahlaklı, erdemli insanlar yetiştirmekten geçer. Kant bunun için de ahlak eğitimine gereken önemin verilmesi gerektiğini söyler.

Ona göre, ruhun fiziki yönden yetiştirilmesi ahlak eğitiminden farklı bir şeydir. Fiziki eğitim doğaya, ahlak eğitimi ise özgürlüğe aittir. Bir kimse fiziki açıdan mükemmel bir şekilde yetiştirilebilir, hatta orijinal düşüncelere de sahip olabilir; ancak ahlaki kültürden yoksun olarak yetiştirilirse sonuçta kötü bir adam olabilir (Kant, 1992:77). Kant'a göre bedeni yönümüze ait eğitim bizim doğal yeteneklerimizi geliştirmeyi hedefler. Doğal yeteneklerimizin gelişmesi bizi doğal bir varlık olarak yetiştirir. Ancak insanın doğal varlık olmasından çok ve daha yüksek bir özelliği vardır. O da özgürlük varlı̆̆ı olmasıdır. Kant insanın özgürlük sayesinde ahlaki bir şahsiyet kazanabileceğini ifade eder. "Ruhun fiziki yönden yetiştirilmesinin ahlak terbiyesinden ayırt edilmesi gerekir. İlkinin doğaya ait olmas1, diğerinin yani ahlak eğitiminin özgürlüğe ait olması itibariyledir" (Kant, 1992:66). Dolayısıyla Kant'ın ahlak eğitimine ilişkin düşüncelerinin etik, ödev ve özgürlük hakkında ileri sürdügü fikirlerle bire bir ilişkili olduğunu söyleyebiliriz.

Kant'a göre fiziki eğitimde çocuk herhangi bir maksimi öğrenme ihtiyacı duymaksızın her şeyin uygulamasına ve disiplinine yönelik bir pratik ile meşgul olmaktadır. Fiziki eğitimde çocuk tamamen pasif olup başkalarının idaresi ve etkisi altındadır. Ahlak eğitimi ise bir disiplin üzerine değil, maksimler üzerine dayanır. Kant'a göre ahlak eğitimi nasihatler, örnekler, tehditler, cezalar, vb. ölçütlere göre verilirse hiçbir sonuç alınamaz. Böyle bir uygulama sadece bir disiplin olacaktır. Oysa Kant çocuğun sadece alışkanlıklarından dolayı değil, bizzat kendi maksimlerini temele alarak eylem gerçekleştirmesini, iyiliği iyilik olduğu için yapmasını arzu eder. Çünkü insan eylemleri bütün ahlaki değerini iyiye ilişkin maksimlerden alır (Kant, 1992:77). Çocuğun, her zaman bir eylemin temelinde yatan prensibi ve onun ödev idesiyle bağlantısını anlayabilecek bir ahlak eğitimiyle yetiştirilmesi gerektiğine inanır .

Görülüyor ki, Kant ahlak eğitiminin disipline değil, birtakım hal ve hareketlerin dayandığı prensipler olan maksimlere göre verilmesi gerektiğini savunur. Çünkü disiplin kötü alışkanlıkları önlerken, maksimler çocuğa düşünmeyi öğretir. Başka bir ifadeyle ahlak eğitimi, çocuğa düşünmeyi 
öğreterek onun maksimlere göre bilinçli eylem gerçekleştirmesinin olanağını sağlar. Kant çocuğun, eylemin sürekli değişen kaynaklara göre değil, değişmez ve genel geçer maksimlere göre hareket etmelerini alıştıracak bir tarzda eğitmemiz gerektiğini öne sürer. Çocuğa öyle bir ahlak eğitimi verilmelidir $\mathrm{ki}$, bu sayede çocuk doğruluğunu bizzat idrak edeceği maksimlere göre hareket etmeyi öğrenebilsin. Böyle bir eğitim ortamının oluşturulması gerek ebeveynler, gerekse de eğitimciler açısından oldukça önemli, önemli olduğu kadar zordur ve bu büyük bir öngörüyü gerektirir (Kant, 1992:83).

Kant'a göre maksimler sadece insanın kendisinden, kendi özerkliğinden kaynaklanmaktadır. Bir baskı ya da zorlama ürünü olmamalıdır. Çocukta ahlaklılık tesis etmek istiyorsak, cezaya dayalı bir yöntemden uzak durmamız gerekir. Kant'a göre ahlaklılık o kadar yüce, kutsal ve ulvi bir şeydir ki, onun cezai yöntemlerle derecesini düşürmemek ve disiplin ile aynı seviyede tutmamak gerekir. Öte yandan Kant'a göre ahlak eğitiminin en temel hedefi, karakteri meydana getirmektir. Karakterin oluşması da ahlak eğitimi aracılığıyla gerçekleştirilecektir. Ona göre karakter, köken itibarıyla doğanın bir ürünü olarak düşünülse bile sonraları insan kendi çabasıyla onu oluşturabilir, tamamlayabilir ve geliştirebilir (Kant, 1992:47). İnsanın karakterini oluşturabilmesi için ortaya koyduğu çabanın özü aslında değişmez ilkelere, kurallara ve evrensel yasalara göre eylemlerde bulunmasıdır. "Ahlak eğitiminin ilk çabası karakterin oluşmasına gayret etmektir. Karakter maksimlere göre hareket etme yeteneğinden ibarettir". Başka bir ifadeyle ahlak eğitiminin hedefi karakterin oluşturulmasıdır ve bunun yolu da değişmez ilkelere, evrensel yasalara göre davranmaya çalışmaktır. Dolayısıyla ahlak eğitimiyle çocuğa kazandırılmaya çalışılacak en temel hedef onu değişmez, evrensel kurallara, ilkelere göre davranmaya alıştırmaktır. Zaten Kant karakteri 'kurallara göre davranma alışkanlığı' olarak tanımlar. "Eğer çocuğun karakterini şekillendirmek istiyorsak dikkat edilmesi gereken en önemli şey çocuklara her şeyde uyacakları belli bir plan ve belli kuralları işaret etmektir" (Kant, 1992:84-85). Kant'a göre çocuk ilk önce okulun kurallarına, daha sonra da insanlık kurallarına göre davranmaya alıştırılmalıdır.

Kant, doğanın birey üzerinde bir disiplin kurduğunu ve doğa yasasına aykırı davranıldığında katı cezalara muhatap kalınıldığını belirtmesine rağmen bunları yeterli görmüyor. Doğa yaptırımlarının dışında çocuğun uymak zorunda olduğu ahlaki bir sorumluluğun olduğunu ve çocuğa ödev alışkanlığının kazandırılması gerektiğine inanır. $\mathrm{Bu}$ nedenle, eğitimde şu kurala büyük önem verir: "Çocuklar iradesiyle ahlak yasasına uyma alışkanlığı kazanmalıdırlar." Yine eğitim aracılığıyla çocuğun itaate alıştırılması gerektiğinin eğitimde önemli bir kural olduğunu belirtir (Kant, 1992:47). 
$\mathrm{Bu}$ aşamada "eğitimin en büyük problemlerinden birisini, çocuğun özgür iradesini kullanabilme kapasitesiyle, itaat zorunluluğunu bir araya nasıl getirebileceğimiz" sorusu oluşturur (Kant, 1992:27). Çocuğun küçük yaşlarından itibaren itaate alıştırılması onun iradesini ortadan kaldırmaz mı? Kant bu soruya hayır cevabını verir ve itaatin, çocuk büyüdügünde kendi kendisine hareket etmesine ve karar vermesine hizmet edeceğini düşünür. Ona göre çocuk ilk yaşlarında içgüdülerin ve duygularının kontrolü altında olduğundan çocuğa itaat duygusu kazandırılmadığında, onun hareketlerine bir yön vermenin, bazı şeyleri öğretmenin ve onu eğitmenin mümkün olamayacağını söyler. Çocuk itaate alıştırılmalıdır. İtaat etme mecburiyeti hoşuna gitmese bile, bunun bir zorunluluk olduğu ona hissettirilmelidir. Böyle yapmakla çocuk, büyüyüp toplumun bir üyesi olduğu zaman kendisinin hoşuna gitmese bile yasalara itaat etmesi gerektiğini anlayacaktır (Kant, 1992:26,86).

\section{SONUÇ}

Sonuç olarak Kant'a göre eğitimin esas amacı ahlak yasasına bağlı bir 'ahlakileşme' ve 'insanileşme' gerçekleştirmektir. İnsan mümkün olduğunca 'ödev' bilinciyle, yani ahlak yasasına göre eylem gerçekleştirmeye, doğası üzerinde hakimiyet kurmaya ve ahlaki açıdan özerk bir şahsiyet geliştirmeye çabalamalıdır. Bunun için de çocukların, mümkün olan en erken yaşlardan itibaren 'ödev' ve 'disipline' alıştırılması gerektiğini savunan Kant, ahlak eğitimini ahlak felsefesine uygun bir tarzda ortaya koyarak, ahlak eğitiminin disiplin üzerine değil, belli kurallara, yasallara dayanması gerektiğini öne sürer. Bunun için de 'öyle bir yasaya göre eylemde bulun ki, bunun genel geçer bir yasa olmasını arzu edebilesin' der. Bu nedenle, ahlak eğitiminde, çocuklara genel kurallar çerçevesinde eylemde bulunmalarının öğretilmesini önerir. Böylece çocuk, doğruluğunu bizzat algıladığı ve kendisinin ortaya koyduğu genel geçer yasaya göre eylemde bulunmayı öğrenir. Bununla birlikte ahlak eğitimi çocuğun karakterinin oluşmasına da zemin hazırlar. Kant'a göre karakter ahlak yasasına göre eylemde bulunma alışkanlığıdır ve karakteri oluşan bir çocuk ahlaki eylemler gerçekleştirebilir. Ayrıca ahlak eğitiminde 'ceza' ve ‘ödülün' yeri olmadığını savunur. Çünkü sadece ceza korkusundan ya da ödül isteğinden dolayı gerçekleştirilen eylemin hiçbir ahlaki değeri yoktur. Ahlaki bir eylem sadece özünde iyi ve erdemli olduğu ve ahlak yasasına uygun bir tarzda gerçekleştirildiği zaman ahlaki bir eylem olur. Çocuğun iyiyi anlamadan, kavramadan istenilen bazı davranışları yapmasının fazlaca bir değeri ve önemi yoktur. Önemli olan iyiliği iyilik olduğu için yapması, kötülüğü de kötülük olduğu için ondan sakınmasıdır. Kant'a göre ahlak eğitimi, çocuğa uyması gereken kuralları baskıya, korkuya dayalı olarak değil, anlamaya, açıklamaya ve benimsemeye dayalı olarak öğretmesi gerekir. Ancak böyle bir ahlak eğitimi çocuğa sağlandığı taktirde , çocuk bilinçli ve ahlaklı eylemler gerçekleştirebilecek ve eğitilmiş sayllabilecektir. 


\section{KAYNAKÇA}

Aytaç, K. (1980). Avrupa Eğitim Tarihi (2. Basım). Ankara: A.Ü. DTCF Yayınları.

Bowyer, C.H. (1970). Philosophical Perspectives for Education. Illinois: Scott, Foresman and Campany.

Churton, A. (1992). Introduction. İn I. Kant (Author), Kant on Educatin. England: Thoemmas Press.

Erişilgil, M.E. (1997). Kant ve Felsefesi. İstanbul: İnsan Yayınları

Kant, I. (1999). Pratik Aklın Eleştirisi (3. Bask1). (Çev. İ.Kuçuradi. \& Ü.Gökberk., F.Akatlı). Ankara: TFK Yayınları.

Kant, I. (1992). Kant on Education (Trans. A. Churton). England: Key Texts.

MacIntyre, A. (2001a) Ethik'in Klsa Tarihi (Çev. H. Hünler. \& S.Z. Hünler). İstanbul:Paradigma Yayınları.

Rousseau, J.J. (2000). Emil ya da Çocuk Eğitimi Üzerine (Çev. Y. Kızılçim). Erzurum: Babil Yayınları. 